\title{
Performance Analysis of Road Segment and Level Crossing (JPL) 340 KM 158+795 as Access to Adisutjipto International Airport of Yogyakarta
}

\author{
Dian M. Setiawan \\ Department of Civil Engineering \\ University of Muhammadiyah Yogyakarta \\ University of Nebraska - Lincoln \\ Nebraska, United States of America \\ dsetiawan2@huskers.unl.edu
}

\author{
Noor Mahmudah \\ Department of Civil Engineering \\ University of Muhammadiyah Yogyakarta \\ Bantul, Indonesia \\ noor.mahmudah@umy.ac.id
}

\author{
Rizqo Hainun Sully \\ Department of Civil Engineering \\ University of Muhammadiyah Yogyakarta \\ Bantul, Indonesia \\ rizqo.hainun.2015@ft.umy.ac.id
}

\begin{abstract}
Roads and rail tracks are land transportation infrastructures that play an essential role in supporting human activities both as passenger and goods transport. One of the problems of land transportation in Indonesia is a large number of level crossings between road and rail track. These level crossings are generally operated semi-automatically, and their operation significantly affects vehicle traffic on the road. This study not only aims to identify traffic parameters on the road and the completeness of the level crossing safety infrastructure but also to analyze the performance of the access road to the Adisutjipto International Airport of Yogyakarta, which intersects with the level crossing of the $340 \mathrm{KM} \mathrm{158+795}$ JPL. The results of the study showed that the traffic flow from the South to the North section was 1484.5 pcu/day, while from the South to the North section was 808.5 pcu/day. Moreover, the average traffic delay was 100.3 seconds with the longest vehicle queue length from the North to the South section was $118 \mathrm{~m}$, while from the South to the North section was $48 \mathrm{~m}$. Lastly, it was concluded that an increase in traffic density of $1 \mathrm{pcu} / \mathrm{km}$ would cause a decrease in vehicle speed by $0.1999 \mathrm{~km} / \mathrm{hour}$.
\end{abstract}

Keywords: delays, level crossings, road performance, traffic density, traffic volume, vehicle queues length

\section{INTRODUCTION}

Road and rail transportation are the main modes of land transportation that are needed by service users because these modes are fundamental to support human activities both as a passenger and for goods transportation. Reference [1] states that roads are land transportation infrastructure that includes all parts of the road, including complimentary structure and device intended for traffic, which are above ground, below ground and water, and above the water surface, except rail track, lorries, and cable access.

Based on [2], the level crossing requirements are:

1. The interval between two consecutive train arrivals is at least 30 minutes.

2. The road that intersecting with the rail track is a road that categorized as class III.

3. The distance between two consecutive level crossings is not less than 800 meters.

4. It is located on the straight section of the rail track and the road.

5. There is a $60 \mathrm{~cm}$ flat surface measured from the outer side of the rail track.
6. The crossing width for a single lane is a maximum of 7 meters.

7. The intersection angle between the rail track and the road must be $90^{\circ}$, and the length of the straight section must be at least 150 meters from the rail track centerline.

Reference [3] states that the following lists are the infrastructure lists that must be equipped in road systems that intersecting with a level crossing:

\section{Warning sign.}

2. Prohibition sign.

3. Road markings.

4. Rumble strips.

5. Median on a 2-lane 2-way road.

6. Red light signals and sound signals.

7. Crossing gate.

According to [4], there are three main variables used to analyze traffic flow, namely speed, volume, and density. Reference [5] and [6] state that traffic flows that use research methods in the form of dynamic traffic management can be utilized to improve the safety of level crossing areas by manipulating traffic signs that can be controlled to display the speed mode of vehicle traffic flow, together with the closing time of the rail track crossing.

One of the problems of transportation in Indonesia is the level crossing between the road and the rail track. In Indonesia, the intersection between these two types of transportation infrastructure has been operated semiautomatically using a crossing gate. Although it has been performed in a semi-automatic method, the level crossing performance is still very influential on traffic on the road. According to [7], the risk assessment of level crossing is considered as a challenging task, and accidents at European level crossing account for about more than $30 \%$ of the entire railway collisions and led to more than 300 deaths every year. In Lithuania, there were 83 accidents at railway level crossings, or $14.4 \%$ from a total of 576 traffic accidents occurred in the infrastructure of JSC "Lithuanian Railways" from 2010 to 2016. The traffic accidents at Lithuanian level crossings caused 21 deaths and 19 heavy injuries, i.e., three deaths or injuries per year [8]. Moreover, as stated by [9], a crash between trains and motorized vehicles led most to level crossing accidents, while the risky behavior of motorists is 
the primary accident's cause. Therefore, motorist behavior at the level crossing is a safety concern that needs special attention care.

Reference [10] in their paper provides several suggestions to reduce accidents at the level crossing. They argued that the police has to focus on dangerous evading crossing barriers. It is also necessary to build grade-separated railway crossings, to completely close duplicate level crossings and the level crossings with low utilization, and to take care of visibility splays by maintaining vegetation and limiting other obstructions. Equally important is raising public awareness in driving schools and through mass media and various campaigns of safety organizations. Furthermore, in order to improve the safety at level crossing, reference [11] in their research had implemented a peculiar system for level crossing monitoring based on a robust radar systems, while reference [12] developed a video tracking method to track precisely the largest number of identified pixels of the tracked objects at level crossing.

The level crossing of JPL 340 KM158+795 is officially guarded by PT. KAI and located to the entrance and exit of Adisutjipto International Airport of Yogyakarta. When the train passes and the gate closes, there will be a very long traffic jam and queue. Therefore, the impact of a level crossing on the service level of vehicles on the road must also be considered. So that it will not become a protracted problem, and that train traffic still become acknowledged as the preferred mode of transportation to overcome congestion [13].

Vehicle queue and traffic delays analysis due to traffic lights and rail track crossing closures using deterministic queuing methods at the Tanjung Barat rail track crossing, Jakarta, had been conducted by [14] and [15]. In addition, based on the results of level crossing gate closure effects analysis on the performance of road traffic at the Semarang Kaligawe and Kaliwungu Kendal, as well as according to the intersection analysis on existing conditions, it shows that the Kaligawe Semarang and Kaliwungu Kendal Roads still able to accommodate vehicle traffic that passing those level crossing [16].

Safety inspections and feasibility studies on level crossings were also carried out by several previous researchers who showed the importance of safety assurance for rail track and vehicle users on the road [17, 18, 19, 20, $21,22,23]$. More than that, analysis of road performance and traffic management is also fundamental to be conducted to know the condition of road network performance [24, 25, 26, 27, 28]. Reference [29] stated that an imbalance between the capacities of the road with the volume of traffic would cause congestion on roads and intersections. Reference [30] also believes that speed is assumed to be the only variable that influences traffic flow.

Seeing the importance of safety at the level crossing of JPL $340 \mathrm{KM} 158+795$ as the entry access of Adisutjipto International Airport of Yogyakarta and their impact on the traffic on the road that passes through it, therefore, it is critical to inspect this level crossing which refers to Indonesian Minister of Transportation Regulation Number
36 the Year 2011, Regulation of the Director-General of Land Transportation Number 770 of 2005, and Indonesian Road Capacity Manual of 1997 concerning Urban Roads [2, $3,31]$.

This study aims to identify traffic parameters on the road and the completeness of the level crossing safety infrastructure, as well as analyze the relationship between speed, volume, and traffic density at the entry road to Adisutjipto International Airport of Yogyakarta which intersects with the level crossing of the $340 \mathrm{KM} 158+795$ JPL. The results of this study are expected to improve road performance and anticipate potential accidents at the level crossing of JPL $340 \mathrm{KM} 158+795$.

\section{MethodS}

This research was conducted with several stages starting from determining the location of the survey, planning the data to be taken in the field, the type of survey to be carried out, the time of the survey in the field, the equipment to be used, and the number of observers.

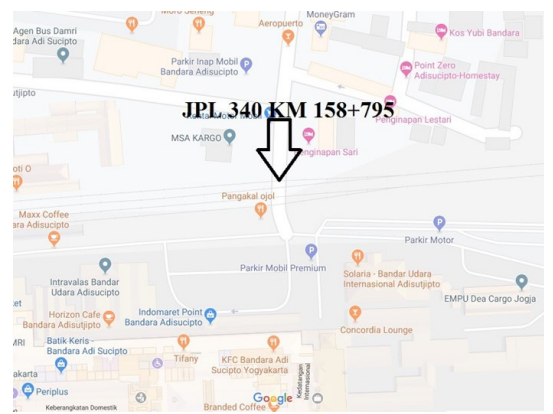

Fig. 1. JPL 340 KM158+795 location [32].

The data taken in this study are the completeness of infrastructure at a level crossing, the duration of the door closure until it opens, the vehicle delay, the length of the vehicle queue, and the traffic flow that is queued. As shown in Fig. 1, this research is located at JPL $340 \mathrm{KM} 158+795$ as entry access of Adisutjipto International Airport of Yogyakarta.

\section{RESUlTS AND DiscUSSION}

\section{A. Completeness of Level Crossing Infrastructure}

Based on the results of field surveys that have been carried out at the level crossing of JPL $340 \mathrm{KM} 158+795$ Adisutjipto International Airport of Yogyakarta on Monday, April 29, 2019, at 06:00 to 19:00 West Indonesia Time, the results are as shown in TABLE I. It can be concluded that the completeness of infrastructure at the level crossing considered as sufficient with the fulfillment of 11 out 15 technical requirements needed to meet the safety aspects at the level crossing.

As for some things that need to be considered is the time interval between two consecutive passing trains which was less than 30 minutes. This is because the railway line that intersects with the road in JPL $340 \mathrm{KM} 158+795$ is one of the main routes that connect the city of Yogyakarta and the surrounding cities. 
TABLE I. COMPLETENESS OF LEVEL CROSSING INFRASTRUCTURE ACCORDING TO REGULATION OF THE INDONESIAN MINISTER OF TRANSPORTATION NUMBER 36 THE YEAR OF 2011

\begin{tabular}{|c|c|c|}
\hline Technical Requirements & Yes & No \\
\hline $\begin{array}{l}\text { The time-lapse between one train and the next train at } \\
\text { least } 30 \text { minutes }\end{array}$ & & $\sqrt{ }$ \\
\hline $\begin{array}{l}\text { The distance between two consecutive level crossings } \\
\text { is not less than } 800 \text { meters }\end{array}$ & $\sqrt{ }$ & \\
\hline $\begin{array}{l}\text { The road that intersecting with the rail track is a road } \\
\text { that is categorized as class III }\end{array}$ & $\sqrt{ }$ & \\
\hline The level crossing is not located on the curve section & $\sqrt{ }$ & \\
\hline $\begin{array}{l}\text { The road surface at a level crossing must have the } \\
\text { same level as a railhead with a tolerance of } 0.5 \mathrm{~cm}\end{array}$ & & $\sqrt{ }$ \\
\hline $\begin{array}{l}\text { The maximum width of the road at the level crossing } \\
\text { for a single lane is } 7 \text { meters }\end{array}$ & $\sqrt{ }$ & \\
\hline $\begin{array}{l}\text { The intersection angle between the rail track and the } \\
\text { road must be } 90^{\circ}\end{array}$ & & $\sqrt{ }$ \\
\hline $\begin{array}{l}\text { The length of the straight road section is at least } 150 \\
\text { meters from the rail track centerline }\end{array}$ & & $\sqrt{ }$ \\
\hline Has complete warning and prohibition signs & $\sqrt{ }$ & \\
\hline Road markings, red light signals and sound signals & $\sqrt{ }$ & \\
\hline $\begin{array}{l}\text { Physical and non-physical facilities at level crossings } \\
\text { in the form of guard posts, JPL officers, bells, list of } \\
\text { the motto, list of Gapeka }\end{array}$ & $\sqrt{ }$ & \\
\hline $\begin{array}{l}\text { The trains become prioritized when the level crossing } \\
\text { gate closed }\end{array}$ & $\sqrt{ }$ & \\
\hline Road users utilized the proper lane & $\sqrt{ }$ & \\
\hline $\begin{array}{l}\text { Road users do not precede each other when the door } \\
\text { is opened }\end{array}$ & $\sqrt{ }$ & \\
\hline
\end{tabular}

In addition, there is a significant difference of height level between the road pavement surface and the rail-head at the level crossing. This difference will lead to the risk of slipping on the vehicle wheels and people who are passing the level crossing. The intersection angle between the rail track and the road also does not meet the applicable requirements since the intersection angle is less than $90^{\circ}$. Moreover, the length of the straight section of the road is less than the minimum requirement of 150 meters from the rail track centerline. Both of these conditions will affect the visibility between the train and vehicle.

\section{B. Traffic Flow}

According to the 1997 Indonesian Road Capacity Manual, traffic flow (Q) for each vehicle movement is converted from vehicles per hour to passenger car units ( $\mathrm{pcu}$ ) per hour. The results of traffic flow surveys can be seen in the following TABLE II.

TABLE II. TRAFFIC FLOW

\begin{tabular}{|l|l|l|l|}
\hline \multirow{2}{*}{ No } & \multirow{2}{*}{ Direction } & \multicolumn{2}{|c|}{ Traffic Flow } \\
\cline { 3 - 4 } & & \multicolumn{1}{|c|}{ Vehicle/day } & pcu/day \\
\hline 1 & South to North & 1659 & 1484.5 \\
\hline 2 & North to South & 901 & 808.5 \\
\hline
\end{tabular}

Based on TABLE II above, it can be concluded that the vehicle traffic from South to North (people who want to enter the Adisutjipto International Airport of Yogyakarta) was higher than the vehicle traffic from North to South.

\section{Speed Analysis}

As shown in Fig. 2, the highest speed of vehicles using the road and crossing the level crossing was identified at 5.08 PM (17.08 WIB) with a speed of $18 \mathrm{~km} /$ hour from the North section, while from the South section, the highest speed of the vehicle is $20 \mathrm{~km} /$ hour at $7.02 \mathrm{PM}$ (19.02 WIB).

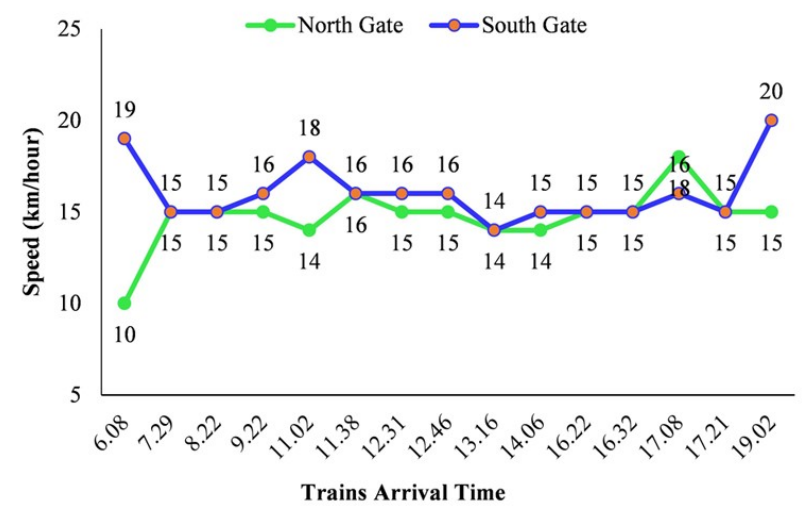

Fig. 2. Vehicle speed.

\section{Density}

Based on the obtained volume and speed data, the road density can then be calculated, as shown in TABLE III and TABLE IV.

TABLE III. VOLUME, SPEED AND DENSITY FROM NORTH TO SOUTH

\begin{tabular}{|l|l|l|l|l|}
\hline \multirow{2}{*}{ No } & \multirow{2}{*}{ Time } & Volume (q) & Speed (Us) & Density (k) \\
\cline { 3 - 5 } & & $\mathbf{p c u} / \mathbf{h o u r}$ & $\mathbf{k m} / \mathbf{h o u r}$ & $\mathbf{p c u} / \mathbf{k m}$ \\
\hline 1 & 6.08 & 80 & 19.06 & 4.20 \\
\hline 2 & 7.29 & 150.4 & 15.01 & 10.02 \\
\hline 3 & 8.22 & 96 & 15.44 & 6.22 \\
\hline 4 & 9.22 & 116 & 16.30 & 7.12 \\
\hline 5 & 11.02 & 194 & 18.71 & 10.37 \\
\hline 6 & 11.38 & 130 & 16.88 & 7.70 \\
\hline 7 & 12.31 & 96 & 18.01 & 5.33 \\
\hline 8 & 12.46 & 124 & 16.33 & 7.59 \\
\hline 9 & 13.16 & 95.2 & 14.31 & 6.65 \\
\hline 10 & 14.06 & 154 & 15.12 & 10.19 \\
\hline 11 & 16.22 & 180 & 15.08 & 11.94 \\
\hline 12 & 16.32 & 178 & 15.31 & 11.63 \\
\hline 13 & 17.08 & 184 & 16.21 & 11.35 \\
\hline 14 & 17.21 & 275.2 & 15.02 & 18.32 \\
\hline 15 & 19.02 & 174 & 16.25 & 10.71 \\
\hline
\end{tabular}

TABLE IV. VOlume, SPEED AND DENSITY From SOUTH TO NORTH

\begin{tabular}{|l|l|l|l|l|}
\hline \multirow{2}{*}{ No } & \multirow{2}{*}{ Time } & Volume (q) & Speed (Us) & Density (k) \\
\cline { 3 - 5 } & & $\mathbf{p c u} / \mathbf{h o u r}$ & $\mathbf{k m} / \mathbf{h o u r}$ & $\mathbf{p c u} / \mathbf{k m}$ \\
\hline 1 & 6.08 & 40 & 10.03 & 3.99 \\
\hline 2 & 7.29 & 58 & 15.9 & 3.65 \\
\hline 3 & 8.22 & 84.4 & 15.12 & 5.58 \\
\hline 4 & 9.22 & 60 & 15.06 & 3.98 \\
\hline 5 & 11.02 & 90 & 14.00 & 6.43 \\
\hline 6 & 11.38 & 92 & 16.09 & 5.72 \\
\hline 7 & 12.31 & 88 & 15.22 & 5.78 \\
\hline 8 & 12.46 & 134 & 15.32 & 8.75 \\
\hline 9 & 13.16 & 116 & 14.11 & 8.22 \\
\hline 10 & 14.06 & 102 & 14.26 & 7.15 \\
\hline 11 & 16.22 & 91.2 & 15.32 & 5.95 \\
\hline 12 & 16.32 & 90 & 15.07 & 5.97 \\
\hline 13 & 17.08 & 20 & 18.06 & 1.11 \\
\hline 14 & 17.21 & 100 & 15.54 & 6.44 \\
\hline 15 & 19.02 & 47.2 & 15.83 & 2.98 \\
\hline
\end{tabular}


Based on TABLE III and TABLE IV above, it can be concluded that the highest density of vehicle traffic that was passing from North to South section occurred at 5.21 PM (17.21 WIB) which is $18.32 \mathrm{pcu} / \mathrm{km}$ while the highest density of vehicle traffic that passing from South to North section occurs at $12.46 \mathrm{PM}$ which is $8.75 \mathrm{pcu} / \mathrm{km}$. Therefore, the higher the traffic volume, the greater the traffic density will be.

\section{E. Delay and Queue Length Analysis}

According to the Indonesian Road Capacity Manual (1997), the delays occur due to two things. Namely, the geometric delay (TG), which occurs because the vehicle stops or turns at an intersection, causing slowdown and speed is interrupted. The second is traffic delays (LL), which occur because of interactions between vehicles in traffic flow in terms of traffic delays of all intersections. Delay stopping results in a time difference between running speed and journey speed. Meanwhile, according to [33], one of the congestion factors at a level crossing is the duration of the closing time when the train crosses the intersection. Therefore, the delay can be formulated as (1) below:

$$
\mathrm{Ts}=\mathrm{t}_{2}-\mathrm{t}_{1}
$$

with:

Ts = Delay (second).

$\mathrm{t}_{1}=$ Travel time when the gate is closed (second).

$t_{2} \quad=$ Travel time when the gate is opened (second).

According to [31], the length of the queue can be defined by identifying the number of vehicles queuing in an approach intersection and expressed in a vehicle or passenger car unit. Therefore, the queue length is defined as the vehicle queue length in an approach and expressed in meters. The movement of vehicles on the queue will be controlled by the vehicle movement on the front side, or the vehicle is stopped by other components of the traffic system.

Based on observation results in Fig. 3 and Fig. 4, 15 trains were passing the JPL 340 level crossing at 06.00 to $09.00,11.00$ to 14.00 , and 16.00 to 19.00 . From the data that has been obtained, the average total delay value is 100.3 seconds; with the longest delay value is 114 seconds, which is occurred at $11.02 \mathrm{AM}$.

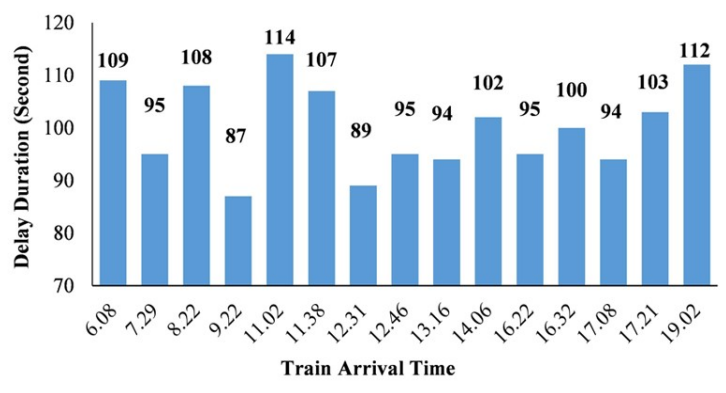

Fig. 3. Delay duration.

As shown in Fig. 3 and Fig. 4, it can be concluded that the highest value of the vehicle delay is 114 seconds at 11.02 $\mathrm{AM}$ while the longest vehicle queue length is 118 meters which occurs at the South Gate at 5.21 PM (17.21 WIB), and 48 meters that occurs at the North Gate at 12.46 PM.

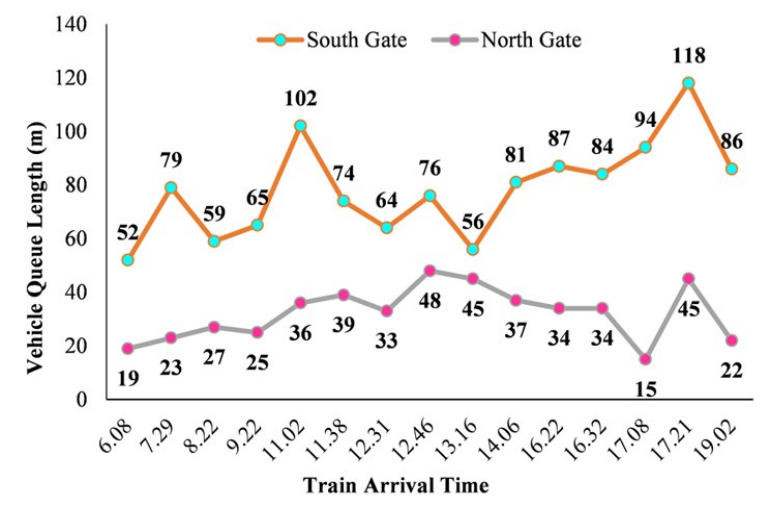

Fig. 4. Queue length.

\section{F. Relationship Between Volume, Speed, and Density}

Based on the regression graph shown in Fig. 5, it can be concluded that the relationship between vehicle speed and traffic density from the North to the South section can be mathematically modeled as $y=17.99-0.1999 x$ with a value of $\mathrm{R}^{2}=0.52$. According to this equation, it can be interpreted that in each addition of $1 \mathrm{pcu} / \mathrm{km}$ of traffic density, there will be a reduction in vehicle speed by $0.1999 \mathrm{~km} /$ hour.

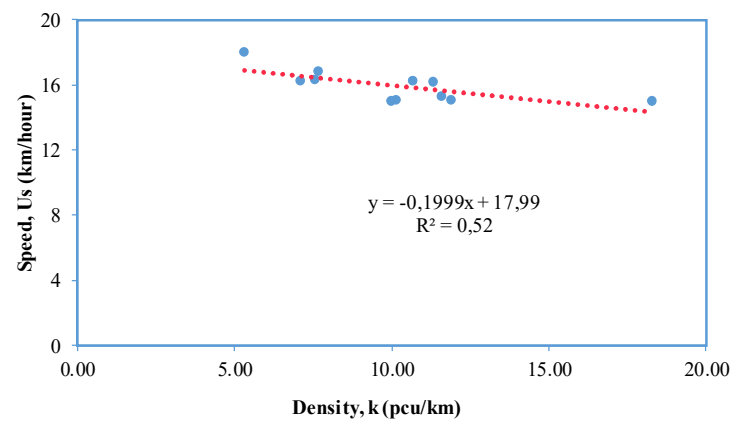

Fig. 5. Density and speed relationship on the North to the South direction.

While based on the regression graph shown in Fig. 6, it can be concluded that the relationship between speed and traffic density from the South to North section can be mathematically modeled as $y=17.8-0.4613 x$ with a value of $\mathrm{R}^{2}=0.696$. So, based on these equations, it can be interpreted that in each addition of $1 \mathrm{pcu} / \mathrm{km}$ of traffic density, there will be a reduction in vehicle speed by $0.4613 \mathrm{~km} / \mathrm{hour}$.

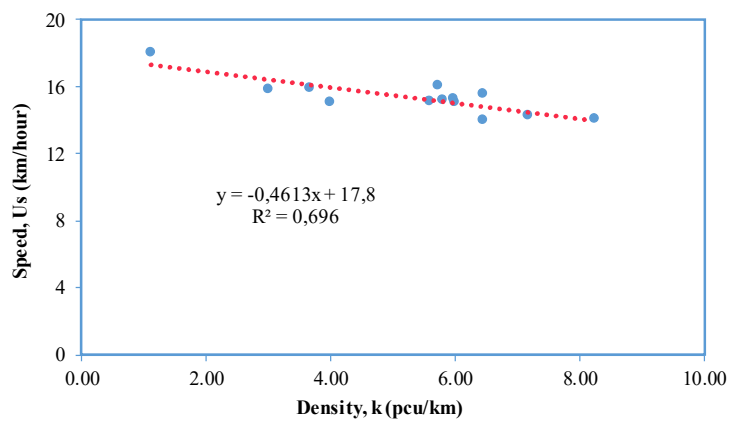

Fig. 6. Density and speed relationship on the South to North direction. 
Based on the regression graph shown in Fig. 7, it can be concluded that the relationship between traffic density and vehicle volume from the North to the South section can be mathematically modeled as $y=19.073+13.869 x$ with a value of $\mathrm{R}^{2}=0.9889$. So, based on these equations, it can be interpreted that in each addition of $1 \mathrm{pcu} / \mathrm{km}$ of traffic density, there will be an increase in vehicle volume of 13.869 $\mathrm{pcu} /$ hour.

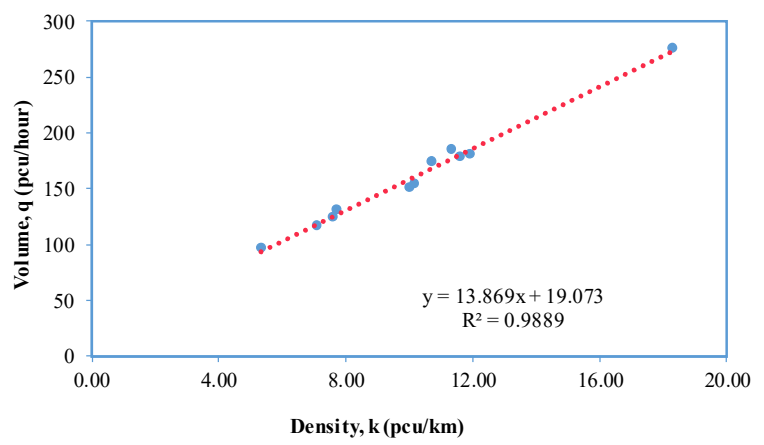

Fig. 7. Density and volume relationship on the North to the South direction.

While based on the regression graph shown in Fig. 8, it can be concluded that the relationship between traffic density and vehicle volume from the South to the North section can be mathematically modeled as $y=0.8598+14.687 x$ with a value of $R^{2}=0.9537$. So, based on these equations, it can be interpreted that in every addition of $1 \mathrm{pcu} / \mathrm{km}$ of traffic density, there will be an increase in vehicle volume of 14.687 $\mathrm{pcu} /$ hour.

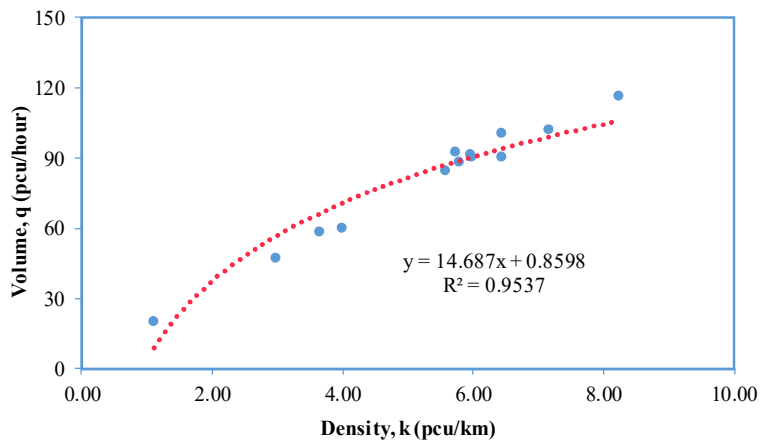

Fig. 8. Density and volume relationship on the South to the North direction.

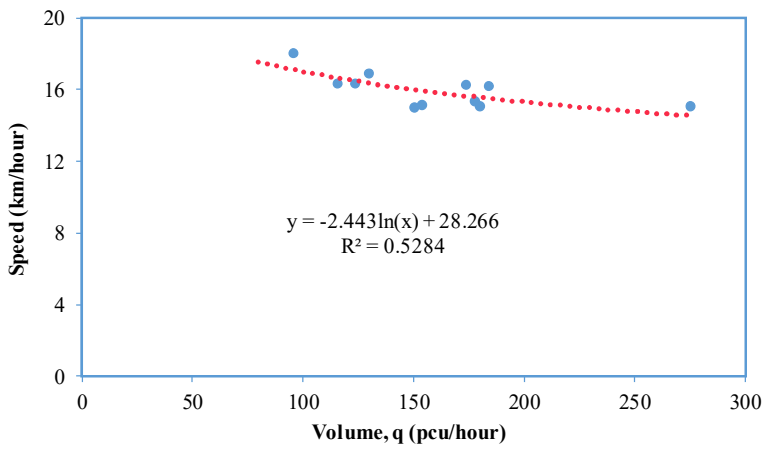

Fig. 9. Volume and speed relationship on the North to the South direction.

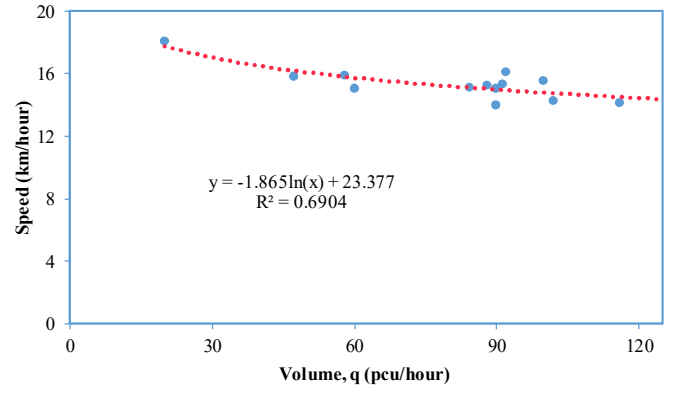

Fig. 10. Volume and speed relationship on the South to the North direction.

While based on the regression graph shown in Fig. 10, it can be concluded that the relationship between volume and vehicle speed from the South to North section can be mathematically modeled as $y=23.377-1.865 \ln (x)$ with a value of $\mathrm{R}^{2}=0.6904$.

\section{CONCLUSIONS}

The following results were obtained based on the analysis that has been presented:

1. The safety infrastructure at the crossing of JPL 340 $\mathrm{KM} 158+795$ is quite complete. However, it is still necessary to be aware of the risk of accidents between road users and rail track vehicles that were passing the level crossings. This is because the traffic on both lanes is classified as dense, and some unfulfilled technical requirements.

2. The results of the traffic parameters survey when the crossing lane is closed to open shows that the value of traffic flow moving from the South to the North section was $1484.5 \mathrm{pcu} /$ day, while the number of traffic flow that moving from the North to the South section was 808.5 $\mathrm{pcu} /$ day.

3. The highest speed of vehicles moving from the North section occurs at 5.08 PM (17.08 WIB) with a speed of $18 \mathrm{~km} /$ hour, while the highest speed of vehicles moving from the South section occurs at 7.02 PM (19.02 WIB) with a speed of $20 \mathrm{~km} /$ hour. Also, the highest delay was 114 seconds, with an average delay of 100.3 seconds. Besides, the longest vehicle queue was $118 \mathrm{~m}$ (South to North) and $48 \mathrm{~m}$ (North to South).

4. The relationship between vehicle speed and traffic density is mathematically modeled as $y=17.99-0.1999 x$ with $\mathrm{R}^{2}=0.52$ for vehicles moving from North to South, and $y=17.8-0.4613 x$ with $R^{2}=0.696$ for vehicles moving from the South towards the North.

5. The relationship between vehicle speed and traffic density is mathematically modeled as $\mathrm{y}=17.99-0.1999 \mathrm{x}$ with $\mathrm{R}^{2}=0.52$ for vehicles moving from North to South, and $y=17.8-0.4613 x$ with $R^{2}=0.696$ for vehicles moving from the South to the North.

6. The relationship between vehicle volume and vehicle speed is modeled as $\mathrm{y}=28.266-2.443 \ln (\mathrm{x})$ with $\mathrm{R}^{2}=0.5284$ for vehicles moving from the North to the South, and $\mathrm{y}=23.377-1.865 \ln (\mathrm{x})$ with $\mathrm{R}^{2}=0.6904$ for vehicles moving from the South to the North. 
There are several suggestions that can be given based on this research process:

1. This study analyzes the performance of roads that intersect with rail tracks at level crossings using data on the duration of delays, length of vehicle queues, and volume of traffic. Future studies are suggested to include the parameters of the degree of saturation to get a more accurate service-level index.

2. This study did not analyze conflicts on roads with level crossings. Future studies are recommended to research the conflicts that occur on these roads.

3. It is expected that there is coordination between related parties with PT. KAI or the Director-General of Railways in planning travel schedules so that the peak hours of the train do not coincide with the peak hours of road traffic.

\section{ACKNOWLEDGMENT}

The authors would like to thank Lembaga Penelitian, Publikasi \& Pengabdian Masyarakat Universitas Muhammadiyah Yogyakarta for the Research Funds.

\section{REFERENCES}

[1] Indonesian Law Number 38 The Year of 2004 concerning the Roads (in Indonesian)

[2] Regulation of the Indonesian Minister of Transportation Number 36 The Year of 2011 concerning the Intersection and/or Intersection between the Railroad Track and Other Buildings (in Indonesian).

[3] Regulation of the Director General of Land Transportation Number 770 of 2005 concerning Technical Guidelines for Leveling Crossings Between Roads and Railways (in Indonesian).

[4] C. J. Khisty and B. K. Lall, Fundamentals of Transportation Engineering (in Indonesian), Vol I. Jakarta: Erlangga Publisher, 2006.

[5] F. D. Hobbs, Traffic Planning and Techniques (in Indonesian), Second Edition. Yogyakarta: Gadjah Mada University Press, 1995.

[6] O. Z. Tamin, Transportation Planning and Modeling (in Indonesian), Second Edition, Bandung: ITB Publisher, 2003.

[7] R. Ravitharan, A. Labrooy, H. Widyastuti, and W. K. Chiu, "Rail infrastructure in Port City-Surabaya, Indonesia," $6^{\text {th }}$ Asia Pacific Workshop on Structural Health Monitoring, $6^{\text {th }}$ APWSHM, Procedia Engineering, vol. 188, pp. 486-492, 2017.

[8] C. Liang, M. Ghazelb, O. Cazierd, and E. El-Koursib, Developing accident prediction model for railway level crossings, Journal of Safety Science, vol. 101(2018), pp. 45-59, 2017. DOI: http://dx.doi.org/10.1016/j.ssci.2017.08.013.

[9] T. Addabbo, C. D. Giovampaola, A. Fort, M. Mugnaini, A. Pozzebon, A. Toccafondi, and V. Vignoli, Target measurements influence on level crossing detection system safety determination, Journal of Measurement, vol. 135 (2019), pp. 547-554, 2019. DOI: https://doi.org/10.1016/j.measurement.2018.11.059.

[10] C. Lianga, M. Ghazelb, O. Cazierd, and E. El-Koursib, Analyzing risky behavior of motorists during the closure cycle of railway level crossings, Journal of Safety Science, vol. 110 (2018), pp. 115-126, 2018. DOI: https://doi.org/10.1016/j.ssci.2017.12.008.

[11] M. Kobosil and J. Novák, Level crossing safety in the Czech Republic," Acta Polytechnica CTU Proceedings, vol. 11, pp. 35-38, 2017. DOI: https://doi.org/10.14311/APP.2017.11.0035.

[12] H. Salmane, L. Khoudour, and Y. Ruichek, Motion-based object tracking method for safety at level crossing, Journal of Electronic Imaging, vol. 25(5), pp. 051208, 2016. DOI: https://doi.org/10.1117/1.JEI.25.5.051208.

[13] G. Bureika, M. Komaiško, and V. Jastremskas, Modelling the ranking of Lithuanian railways level crossing by safety level, Journal of Transport Problems, vol. 12 Issue: Special Edition. pp. 11-22. DOI: https://doi.org/10.20858/tp.2017.12.se.1.
[14] N. Winarsih and Nahdalina, Queue and Delay Analysis Due to Traffic Lights and Railroad Crossing Using the Deterministic Queue Method: Tanjung Barat South Jakarta Railroad Crossing Case Study (in Indonesian), Design Construction Journal, vol. 16(1), pp. 32-45, 2017.

[15] M. Djaelani, The Effect of Closing the Railroad Crossing on the Delay and Queue Length of Vehicles on Jalan Bung Tomo Surabaya (in Indonesian), Civil Engineering Journal, vol. 7(1), pp. 23-30, 2014.

[16] M. Yusyadiputra, The effect of Closing the Railroad Crossing Door on the Highway Traffic Performance at the Semarang Kaligawe and Kaliwungu Kendal Crossings (in Indonesian), Final Exam, Civil Engineering, Diponegoro University, Semarang, 2014.

[17] D. M. Setiawan, M. Sari, and N. Mahmudah, Safety Inspection on Level Crossing JPL 727 KM 537+453 Patak-Pathukan Road, Sleman, Yogyakarta, MATEC Web Conf., 181 (2018) 04005, 2018. DOI: https://doi.org/10.1051/matecconf/201818104005.

[18] Y. Aswad, Feasibility Study of Level Crossings on Inner and Intercity Road Networks (in Indonesian), Journal of Civil Engineering Communication Media, vol. 10(2), pp. 183-189, 2010.

[19] Hartono, Railroad Crossing in the City of Cirebon (in Indonesian), Journal of Land Transportation Research, vol. 18(1), pp. 45-62, 2016.

[20] R. K. Putra, Safety Inspection at Level Crossing at JPL $163+220$, Sorowajan Baru Street, Yogyakarta City (in Indonesian), Final Exam, Civil Engineering, University of Muhammadiyah Yogyakarta, Yogyakarta, 2017.

[21] D. M. Setiawan and N. Mahmudah, Road Safety Inspection in Yogyakarta (Case Study: Wates-Yogyakarta Rroad KM 5 to KM 10) (in Indonesian), 11th National Civil Engineering Conference of Tarumanegara University, October $26^{\text {th }}-27^{\text {th }} 2017$.

[22] R. D. Ramanti, Safety Inspection at Level Crossing at JPL 349 KM $163+758$, Timoho Street, Yogyakarta (in Indonesian), Final Exam, Civil Engineering, University of Muhammadiyah Yogyakarta, Yogyakarta, 2017.

[23] F. P. Sitorus and M. S. Surbakti, Effect of Railroad Crossing on Railroad Characteristics on Traffic Characteristics: Case Study of Railroad Crossing in Sisimangaraja Street Medan (in Indonesian), USU Civil Engineering Journal, vol. 2(2), pp. 1-11, 2013.

[24] A. Alhadar, Analysis of Road Performance in an Effort to Overcome Traffic Congestion at Signalized Intersections in Palu City (in Indonesian), SMARTeK, vol. 9 (4), pp. 327-336, 2011.

[25] W. Adisatria, L. Djakfar, and A. Wicaksono, Traffic Management in the Pasar Tanjung Area of Jember Regency (in Indonesian), Journal of Civil Engineering, vol. 9, No.1 - 2015 ISSN 1978 - 5658, 2017.

[26] A. Afifi, K. P. Aurum, Usman, and S. S. Gondoarum, Traffic Management and Engineering with Performance Analysis and Road Damage on Non-Toll Road Sections During Repairs to the Cisomang Bridge (in Indonesian), Journal of Infrastructure, vol. 3(02), pp. 1-17, 2017.

[27] A. Rumayar, A. Palin, and E. Lintong, Capacity and Service Level Analysis at Wolter Monginsidi Street in Manado City (in Indonesian), Static Civil Journal, vol. 1(9), pp. 2337-6732, 2013.

[28] Y. Fauzi and H. Widyastuti, Analysis of Changes in Performance on Gajah Mada Street Medan Due to the Overpass (in Indonesian), ITS Civil Engineering Journal, vol. 32(2), pp. 47-52, 2017.

[29] N. Mahmudah, R. Akbar, and Muchlisin, Analysis of congestion cost at signalized intersection using Vissim 9 (Case study at Demak Ijo Intersection, Sleman), Proceeding of the $1^{\text {st }}$ International Symposium on Transportation Studies in Developing Countries (ISTSDC 2017), Matec Web Conferences, vol. 181, 2018. DOI: https://doi.org/10.1051/matecconf/201818106001.

[30] M. G. Lay, Handbook of Road Technology, Volume 2, Traffic and Transport, New York: Gordon and Breach, 1986.

[31] Indonesian Road Capacity Manual 1997 (in Indonesian).

[32] www.googlemaps.https://www.google.com/maps/@7.7844416,110.4354949,17z, retrieved September $25^{\text {th }} 2019$.

[33] A. Utami and H. Widyastuti, Model of Vehicle Queue Length at Level Crossings Without Doorstop (Case Study: Level Crossings Gayung Street Kebonsari Surabaya) (in Indonesian), Journal of Civil Engineering Applications, vol. 17(1), pp. 27-34, 2019. 